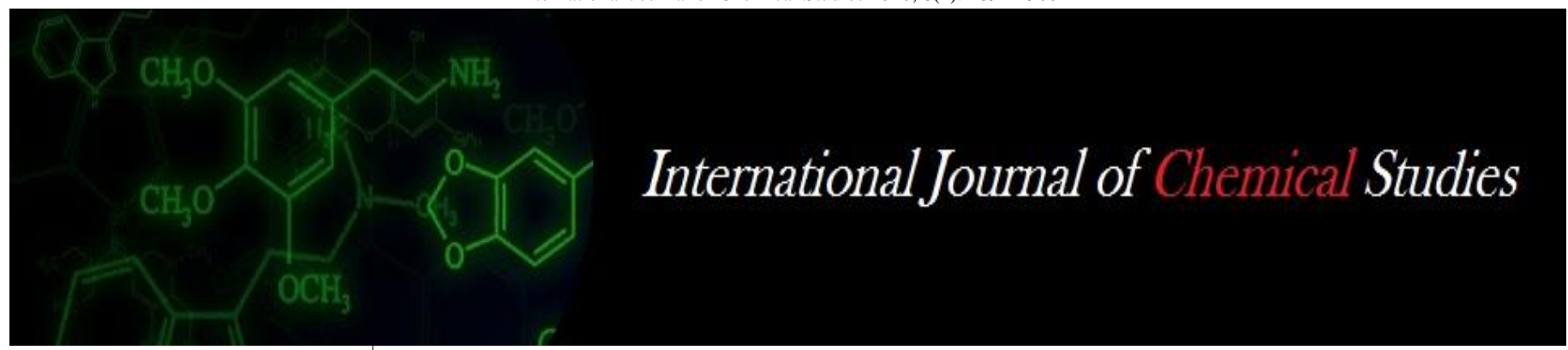

P-ISSN: 2349-8528

E-ISSN: 2321-4902

www.chemijournal.com

IJCS 2020; 8(2): 1892-1900

(C) 2020 IJCS

Received: 15-01-2020

Accepted: 16-02-2020

Prem Chand Meena

Principal Scientist,

Finance Management, National

Academic of Agricultural

Research Management,

Hyderabad, Telangana, India

Phool Chand Meena

Assistant Professor, COA,

Sumerpur, Agricultural

University, Jodhpur, Rajasthan,

India

\section{Sanjiv Kumar}

Scientist, National Academic of

Agricultural Research

Management, Hyderabad,

Telangana, India

Sivaramne N

Principal Scientist, National Academic of Agricultural

Research Management,

Hyderabad, Telangana, India

Corresponding Author:

Prem Chand Meena

Principal Scientist,

Finance Management, National

Academic of Agricultural

Research Management,

Hyderabad, Telangana, India

\section{Regional stylization of consumer expenditure with a specific reference to food articles}

\author{
Prem Chand Meena, Phool Chand Meena, Sanjiv Kumar and Sivaramne N
}

DOI: https://doi.org/10.22271/chemi.2020.v8.i2ac.9034

\begin{abstract}
The paper aims to analyse consumer expenditure pattern in general and expenditure on different food items in particular across the regions and expenditure classes. The present analysis is based on the Unit Level Data of CES, $68^{\text {th }}$ round (2011-12) with an URP as a reference period. All the States and Union Territories were categorized in four zones (East, North, South \& West). The analyses have been carried out at regional and national level for both rural and urban sector separately. Summarily, the stylization of regions has been done based on the food habits and pattern in consumption expenditure.
\end{abstract}

Keywords: Diet pattern, food items, consumer expenditure, taste and preferences, local availability

\section{Introduction}

India is a diverse country and it can be safely assumed that no other country in the world is blessed with such rich diversity. Languages, tradition, life styles etc. are distinctly different in each region of the country. Consumption pattern is no exception. Through this paper we have attempted to bring out this divergence in consumption pattern in different regions of the country.

In the recent years, India has also witnessed a great shift in dietary preference of people. This change has been more pronounced in the post-liberalization era. India not only experienced rapid economic transformation but also substantial changes in many other dimensions of wellbeing, including in its diet pattern (Ali 2007; Atibudhi 2006; Giri 2006; Golait and Pradhan 2006; Nasurudeen et al. 2006; Radhakrishna 2006; Singh et al.2006; Viswanathan 2001; Shariff and Mallick 1999; Radhakrishna and Reddy 2004) $[1,2,5,6,11,13,17,18,16,14]$. There is a trend of declining cereal intake particularly coarse cereals and very low increase of consumption of other food items in the rural diet, which has often been explained as an expected outcome of economic growth. Diets evolve over time and are influenced by factors such as income, prices, individual preferences and beliefs, cultural traditions, as well as geographical, environmental, social and economic factors. In India over the past two decades this diet diversification may be mainly income induced, impact of globalization, increasing urbanization and changing lifestyle of people (NCAER 2014) ${ }^{[12]}$. Also, better awareness about the nutritional value of different food items which leads to people making more informed choices may have contributed to this change in the diets. To ascertain which factor contributed how much to the changemay be an interesting topic for a separate research.

These changes in diet pattern, however, are not uniform rather they vary across various socio economic groups (Gupta and Mishra 2013) ${ }^{[7]}$. There are distinct food regions in India. It is well known that wheat is much preferred in northern and central region, and rice in the southern and eastern region. Western region displays higher relative consumption of coarse cereals. In rural India, meat consumption is quite low however its higher consumption is mainly seen in western coastal region. There are number of factors which make and shape food regions such as food culture, taste and preferences, local availability, market, income etc. (Gupta and Mishra 2014) ${ }^{[8]}$

\section{Data Source}

The Surveys of National Sample Survey Organisation (NSSO) are the most important and regular source of information of consumer surveys on different themes like consumer expenditure, nutrition, education, employment, health and housing, migration, 
wages and other issues of contemporary importance. Due to its pan-India coverage, the results of such surveys have been used in devising and evaluating various policies and programmes and their welfare effects. Some examples include examining equity and efficiency effects of transfers and taxes, nutritional benefits of food subsidies, and planning for different sectors of economy (Deaton, 1997; Murthy, 1967) ${ }^{[4,}$ ${ }^{10]}$. In absence any other source of reliable information, these periodical surveys assume greater importance and reliance on such 'natural experiments' increases and are often used for evaluating the impact of many economic and social policies.

The Consumer Expenditure Surveys (CES) of National Sample Survey Organization (NSSO) are the most important and regular source of information of consumer surveys of different food and non-food items in India. The country has vast geographical spread, diverse topography and cultural variety and the same is reflected in the food habits too. While the publications of the CES provide information on various food articles for major states, the pattern across the regions is an area of interest to study in detail. The paper aims to analyse consumer expenditure pattern in general and in food items in particular across the regions and expenditure classes, which is not readily available otherwise.

\section{Methodology}

The National Sample Survey (NSS) regularly conducts surveys covering the entire country on various parameters and issues which are of national interest. These surveys can be broadly categorized into two viz. thin and quinquennial rounds. Thin rounds are generally conducted on annual basis involving smaller sample size whereas the quinquennial rounds have much larger sample size and conducted at an interval of 5 years. The importance of data collected through these surveys is very high as it is the only source of such robust and comprehensive information in the country and most of the government policies and programmes are heavily dependent on it for taking critical decisions. There are data pertaining to several parameters which helps in estimating consumers' expenditure on various items both in rural and urban sector, state-wise which are then aggregated to the national level.

The Unit level data of $68^{\text {th }}$ Round of CES for the year 2011-12 (CES, 2014) ${ }^{[3]}$ has been used for present analysis. The reference period used for above information is "Uniform Reference Period (URP)". This is the measure of Monthly Per Capita Expenditure (MPCE)obtained by the NSS consumer expenditure survey when household consumer expenditure on each item is recorded for a reference period of "last 30 days" (preceding the date of survey).

The published reports of CES generally provide different fractile classes of MPCE distribution. However, for the ease of understanding, the pentile classes of MPCE distribution have been constructed. The first pentile of the distribution of MPCE over population of any region or domain is the level of MPCE below which $20 \%$ of the population lie, the second pentile, the level below which $40 \%$ of the population lie, and so on. In short, the population has been divided into 5 classes of MPCE. Pentile classes are formed separately for the rural and the urban sector of India and denoted as $\mathrm{MPCE}_{20}$.

The States and Union Territories as reported in the data are categorized in four regions viz., East, North, South and West, as provided below.

Table 1: States and regions

\begin{tabular}{|c|c|}
\hline Region & State \\
\hline East & $\begin{array}{c}\text { Arunachal Pradesh, Assam, Bihar, Jharkhand, Manipur, Meghalaya, Mizoram, Nagaland, Orissa, Sikkim, Tripura, West } \\
\text { Bengal, A \& N Island }\end{array}$ \\
\hline North & Haryana, Himachal Pradesh, Jammu \& Kashmir, Punjab, Rajasthan, Uttar Pradesh, Uttaranchal, Delhi, Chandigarh \\
\hline South & Andhra Pradesh, Karnataka, Kerala, Tamil Nadu, Pondicherry, Lakshadweep \\
\hline West & Chhattisgarh, Goa, Gujarat, Madhya Pradesh, Maharashtra, D \& N Haveli, Daman \& Diu \\
\hline
\end{tabular}

In order to show effect of socio-economic and regional variables on consumer expenditure on different food items, a multiple regression analysis has been attempted. The following socio-economic and regional variables have been selected and recoded from the NSS $68^{\text {th }}$ round (2011-12) unit level data.

\section{- Household Size}

- Regions: All states and Union Territories have been categorized into four regions, as mentioned above: North, East, West \& South. In multiple regressions, "North" is the reference category.

- Occupation Type (Household Type): There are different types of rural occupations, as provided in the unit level data. For Rural: (i) self-employed in agriculture, (ii) self-employed in non-agriculture, (iii) regular wage/ salary earnings, (iv) casual labour in agriculture, (v) casual labour in non-agriculture, and (vi) other occupations. Similarly, for Urban: (i) selfemployed, (ii) regular wage/ salary earnings, (iii) casual labour, and (iv) other occupations.

In multiple linear regressions, "self-employed in nonagriculture" is the reference category in Rural areas, whereas "regular wage/salary earnings" has been taken as a reference category.

- Social class: Scheduled Tribe (ST), Scheduled Caste (SC), Other Backward class(OBC) and 'Others', where 'others' is the reference category.

\section{Results and Discussions \\ Region-wise population}

To begin with, it is necessary to understand the population distribution across the regions. In the CES 2011-12, the estimated human population was 792 million and 317 million in rural and urban areas respectively. In rural area, the Northern region accounted for $31 \%$ of total population, closely followed by the Eastern region (30\%). In urban area, the Western region has the highest population share of 30\%, followed by the Northern (28\%) and Southern region (27\%). At the country level, $71 \%$ of population lived in the rural sector and the balance $29 \%$ in the urban sector. Across the regions, the Eastern and Northern regions have higher percentage of rural population ( $83 \%$ and $74 \%$ respectively) as compared to national proportion, whereas Western and Southern regions have relatively higher proportions of urban population (37\% and $36 \%$ respectively) as against the national average. 


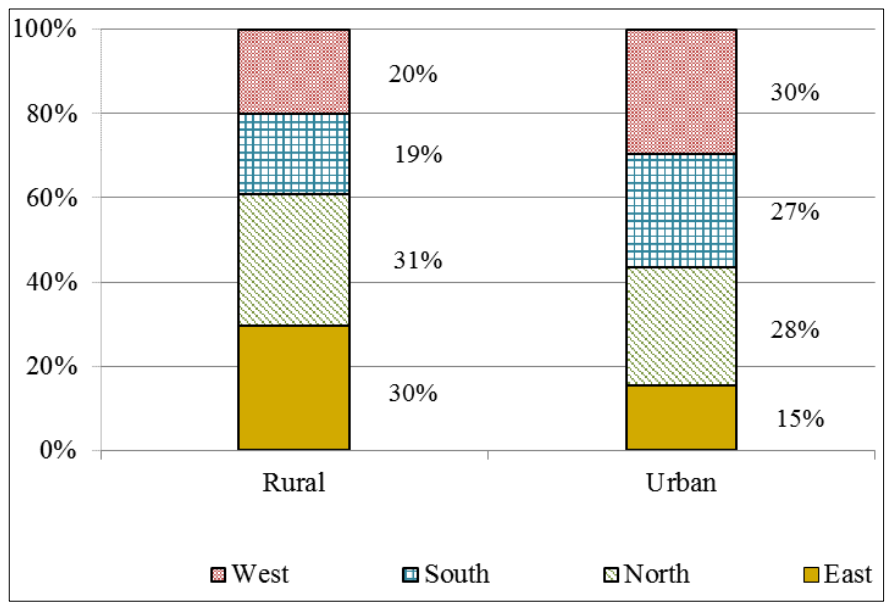

Graph 1: Region-wise population

\section{Distribution of population by MPCE20}

The distribution of rural population across $\mathrm{MPCE}_{20}$ exhibit that the proportions of population belonging to pentile class 1 and 2 were relatively higher in Eastern region, whereas the population was highly skewed towards pentile class $4 \& 5$ in Southern region, followed by Northern region. The Western

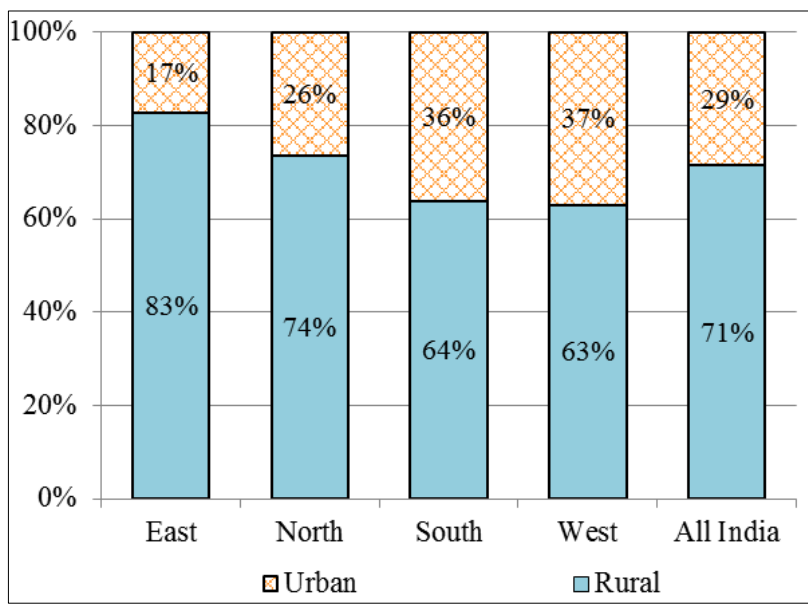

Graph 2: Rural and Urban Population

region broadly followed the national distribution of population across $\mathrm{MPCE}_{20}$ classes. In urban sector, the Eastern and Northern regions had relatively higher population in $\mathrm{MPCE}_{20}$ class $1 \& 2$, while Southern and Western regions have more people belonging to $\mathrm{MPCE}_{20}$ class 3, 4 and 5 .

Table 2: Distribution of population by $\mathrm{MPCE}_{20}$

\begin{tabular}{|c|c|c|c|c|c|c|c|c|c|c|}
\hline \multirow{2}{*}{ MPCE20 } & \multicolumn{9}{|c|}{ Rural } & \multicolumn{5}{c|}{ Urban } \\
\cline { 2 - 12 } & East & North & South & West & All India & East & North & South & West & All India \\
\hline 1 & 28 & 19 & 8 & 20 & 20 & 29 & 25 & 14 & 16 & 20 \\
\hline 2 & 25 & 19 & 16 & 20 & 20 & 21 & 20 & 20 & 19 & 20 \\
\hline 3 & 20 & 19 & 20 & 19 & 20 & 18 & 18 & 21 & 22 & 20 \\
\hline 4 & 17 & 20 & 25 & 22 & 20 & 18 & 17 & 22 & 22 & 20 \\
\hline 5 & 10 & 23 & 31 & 19 & 20 & 14 & 19 & 23 & 21 & 20 \\
\hline All & 100 & 100 & 100 & 100 & 100 & 100 & 100 & 100 & 100 & 100 \\
\hline
\end{tabular}

\section{Share of food expenditure}

At the country level, the total monthly per capita expenditure (MPCE) stood at ₹1,279 in rural sector and ₹2,399 in urban sector. Across the regions, the Southern region reported higher MPCE both in rural and urban sector, whereas, Eastern region had lower MPCE in rural and urban sectors than that of national average.

At the country level, $49 \%$ of total expenditure is shared by food items in rural sector and the same was $38 \%$ in urban sector. In Eastern region, the share of food expenditure was relatively higher in rural and urban sectors. With the advancement in $\mathrm{MPCE}_{20}$ classes, the share of food expenditure reduced substantially from $57 \%$ to $28 \%$ in urban sector than the rural sector $(61 \%$ to $38 \%)$. Among the regions, the decline in the share of food expenditure was relatively higher in Southern region in rural sector with the improvement in per capita expenditure in comparison to the same at the national level. For instance, in rural sector, the proportion of food expenditure in total MPCE declined by 23 percentage points at the country level from $\mathrm{MPCE}_{20}$ Class 1 to 5 , the same dropped by 27 percentage points in the Southern region. Unlike rural sector, the reduction in the proportion of food expenditure in total MPCE with the progression of $\mathrm{MPCE}_{20}$ was in tandem with the national pattern across all regions in urban sector, except Western region.

Table 3: Share of food expenditure in total MPCE by $\mathrm{MPCE}_{20}$ classes

\begin{tabular}{|c|c|c|c|c|c|c|c|c|c|c|}
\hline \multirow{2}{*}{ MPCE20 } & \multicolumn{4}{|c|}{ Rural } & \multicolumn{5}{c|}{ Urban } \\
\cline { 2 - 12 } & East & North & South & West & All India & East & North & South & West & All India \\
\hline 1 & 63 & 60 & 61 & 59 & 61 & 59 & 57 & 55 & 55 & 57 \\
\hline 2 & 60 & 57 & 59 & 57 & 58 & 54 & 52 & 51 & 52 & 52 \\
\hline 3 & 57 & 54 & 56 & 55 & 55 & 48 & 47 & 46 & 48 & 47 \\
\hline 4 & 53 & 52 & 53 & 51 & 52 & 42 & 42 & 41 & 43 & 42 \\
\hline 5 & 42 & 41 & 34 & 37 & 38 & 29 & 29 & 26 & 30 & 28 \\
\hline All & 54 & 49 & 44 & 48 & 49 & 41 & 39 & 36 & 39 & 38 \\
\hline Total MPCE (₹) & 1032 & 1304 & 1646 & 1258 & 1279 & 2073 & 2325 & 2620 & 2437 & 2399 \\
\hline
\end{tabular}

\section{Monthly per capita expenditure and incidence of consumption}

In rural sector, almost cent-percent population reported consumption of cereals, pulses, oil and vegetables and more than $90 \%$ reported consumption of beverages and processes food. The proportion of population indicated expenditure towards milk \& milk products; egg, fish \& meat and fruits varied across the regions. Lowest incidence of expenditure towards milk \& milk products was noticed in the Eastern region $(74 \%)$, followed by the Western region (82\%) in 
comparison to the national average of $85 \%$. Similarly, as against two-third of total population reported expenditure towards egg, fish \& meat at the all India level, it was only about one-third in the Northern region, followed by $48 \%$ in the Western region. The incidence of fruit consumption was relatively lower in the Eastern region (70\%) as compared to national average of $83 \%$.

In terms of expenditure, the inter-regional variations in expenditure towards cereals, pulses, oil and vegetables were low, moderate variations in case of beverages and processed food and higher variations in milk \& milk products, egg, fish $\&$ meat and fruits. For example, the expenditure on milk \& milk products in the Northern region was $65 \%$ higher than national average of ₹ 116 . Similarly, the consumer expenditure on egg, fish \& meat was $88 \%$ higher in Southern region than the average of ₹46 at all India level. If the same is compared across the regions, the expenditure towards milk \& milk products in Northern region was almost 3.4 times the expenditure in Eastern region. Likewise, the expenditure on egg, fish \& meat in the Southern region was 4.5 times the same in the Northern region.

Milk \& milk products and egg, fish \& meat are the major sources of animal protein for human beings. If both of them are combined, the relative expenditure towards these was lower in the Eastern and Western regions in comparison to national aggregates, whereas it was the highest in the
Northern region, followed by the Southern region. However, the subtle difference is - in the Northern region, the contribution of milk \& milk products was close to $90 \%$ in expenditure towards animal protein food items, while the same was almost equally distributed between milk \& milk products and egg, fish \& meat in the Southern region.

In terms of incidence of consumption, similar pattern like in the rural sector was witnessed in urban sector in cereal, pulses, oil, vegetables, fruits, beverages and processed food. Also, the variations in expenditure across the regions in above items were relatively lower than that of rural sector. As far as consumption expenditure on milk \& milk products is concerned, the urban sector showed almost similar pattern as it was in the rural sector, however, the inter-regional variation in value of expenditure was lower as compared to rural sector. While at the national level, the incidence of expenditure towards egg-fish \& meat remained same at $63 \%$, yet there were regional diversions. In Northern and Western regions, the incidence of expenditure towards egg-fish \& meat was higher compared to the same in rural sector. The value of MPCE towards egg, fish and meat was the highest in the Eastern region in urban sector, which was not the case in rural sector. On the whole, it can be summarized that in terms of intake of animal protein foods in urban sector, the Northern and Southern regions were relatively better off, while it was the least in the Western region.

Table 4(a): Region-wise expenditure and population reported consumption of various food items Rural

\begin{tabular}{|c|c|c|c|c|c|c|}
\hline Item & Particulars & East & North & South & West & All India \\
\hline \multirow{3}{*}{ Cereal\& cereal sub. } & $\%$ Population reported consumption & 100 & 100 & 99 & 99 & 100 \\
\hline & Value of per capita consumption (₹) & 183 & 132 & 160 & 140 & 154 \\
\hline & $\%$ Deviation in value w.r.t. national avg. & $119 \%$ & $85 \%$ & $104 \%$ & $91 \%$ & \\
\hline \multirow{3}{*}{ Pulses } & $\%$ Population reported consumption & 99 & 99 & 99 & 99 & 99 \\
\hline & Value of per capita consumption (₹) & 32 & 41 & 51 & 49 & 42 \\
\hline & \% Deviation in value w.r.t. national avg. & $76 \%$ & $99 \%$ & $122 \%$ & $117 \%$ & \\
\hline \multirow{3}{*}{ Oil } & $\%$ Population reported consumption & 100 & 99 & 99 & 99 & 99 \\
\hline & Value of per capita consumption (₹) & 43 & 47 & 46 & 59 & 48 \\
\hline & \% Deviation in value w.r.t. national avg. & $89 \%$ & $98 \%$ & $95 \%$ & $123 \%$ & \\
\hline \multirow{3}{*}{ Milk \& milk products } & $\%$ Population reported consumption & 74 & 92 & 93 & 82 & 85 \\
\hline & Value of per capita consumption $(₹)$ & 57 & 192 & 93 & 108 & 116 \\
\hline & \% Deviation in value w.r.t. national avg. & $49 \%$ & $165 \%$ & $80 \%$ & $93 \%$ & \\
\hline \multirow{3}{*}{ Egg, fish \& meat } & $\%$ Population reported consumption & 87 & 36 & 86 & 48 & 63 \\
\hline & Value of per capita consumption (₹) & 63 & 19 & 86 & 24 & 46 \\
\hline & $\%$ Deviation in value w.r.t. national avg. & $138 \%$ & $41 \%$ & $188 \%$ & $53 \%$ & \\
\hline \multirow{3}{*}{ Vegetables } & $\%$ Population reported consumption & 100 & 100 & 99 & 99 & 100 \\
\hline & Value of per capita consumption (₹) & 68 & 59 & 61 & 57 & 62 \\
\hline & \% Deviation in value w.r.t. national avg. & $110 \%$ & $96 \%$ & $99 \%$ & $92 \%$ & \\
\hline \multirow{3}{*}{ Fruits (Fresh \& dry) } & $\%$ Population reported consumption & 70 & 82 & 98 & 89 & 83 \\
\hline & Value of per capita consumption (₹) & 13 & 21 & 45 & 29 & 25 \\
\hline & $\%$ Deviation in value w.r.t. national avg. & $54 \%$ & $85 \%$ & $180 \%$ & $115 \%$ & \\
\hline \multirow{3}{*}{ Beverages } & $\%$ Population reported consumption & 92 & 98 & 99 & 98 & 96 \\
\hline & Value of per capita consumption (₹) & 13 & 21 & 32 & 21 & 21 \\
\hline & $\%$ Deviation in value w.r.t. national avg. & $64 \%$ & $101 \%$ & $154 \%$ & $101 \%$ & \\
\hline \multirow{3}{*}{ Processed food } & $\%$ Population reported consumption & 97 & 95 & 93 & 92 & 94 \\
\hline & Value of per capita consumption (₹) & 45 & 45 & 82 & 53 & 54 \\
\hline & \% Deviation in value w.r.t. national avg. & $84 \%$ & $83 \%$ & $154 \%$ & $98 \%$ & \\
\hline
\end{tabular}

Table 4b: Region-wise expenditure and population reported consumption of various food items

Urban

\begin{tabular}{|c|c|c|c|c|c|c|}
\hline Item & Particulars & East & North & South & West & All India \\
\hline \multirow{3}{*}{ Cereal\& cereal sub. } & \% Population reported consumption & 99 & 99 & 97 & 98 & 98 \\
\cline { 2 - 6 } & Value of per capita consumption (₹) & 209 & 151 & 189 & 173 & 177 \\
\cline { 2 - 7 } & \% Deviation in value w.r.t. national avg. & $118 \%$ & $86 \%$ & $107 \%$ & $98 \%$ & \\
\hline \multirow{2}{*}{ Pulses } & \% Population reported consumption & 98 & 98 & 97 & 98 & 98 \\
\cline { 2 - 7 } & Value of per capita consumption (₹) & 41 & 50 & 61 & 60 & 54 \\
\hline
\end{tabular}




\begin{tabular}{|c|c|c|c|c|c|c|}
\hline & \% Deviation in value w.r.t. national avg. & $74 \%$ & $92 \%$ & $112 \%$ & $110 \%$ & \\
\hline \multirow{3}{*}{ Oil } & $\%$ Population reported consumption & 98 & 99 & 97 & 98 & 98 \\
\hline & Value of per capita consumption (₹) & 60 & 59 & 54 & 79 & 64 \\
\hline & \% Deviation in value w.r.t. national avg. & $95 \%$ & $93 \%$ & $84 \%$ & $124 \%$ & \\
\hline \multirow{3}{*}{ Milk \& milk products } & $\%$ Population reported consumption & 85 & 97 & 96 & 95 & 94 \\
\hline & Value of per capita consumption (₹) & 92 & 269 & 146 & 195 & 186 \\
\hline & $\%$ Deviation in value w.r.t. national avg. & $49 \%$ & $144 \%$ & $78 \%$ & $105 \%$ & \\
\hline \multirow{3}{*}{ Egg, fish \& meat } & $\%$ Population reported consumption & 87 & 43 & 83 & 51 & 63 \\
\hline & Value of per capita consumption (₹) & 126 & 29 & 94 & 47 & 67 \\
\hline & \% Deviation in value w.r.t. national avg. & $188 \%$ & $44 \%$ & $141 \%$ & $70 \%$ & \\
\hline \multirow{3}{*}{ Vegetables } & $\%$ Population reported consumption & 98 & 99 & 97 & 98 & 98 \\
\hline & Value of per capita consumption (₹) & 92 & 80 & 71 & 87 & 81 \\
\hline & $\%$ Deviation in value w.r.t. national avg. & $113 \%$ & $99 \%$ & $87 \%$ & $106 \%$ & \\
\hline \multirow{3}{*}{ Fruits (Fresh \& dry) } & $\%$ Population reported consumption & 83 & 90 & 99 & 95 & 93 \\
\hline & Value of per capita consumption (₹) & 35 & 48 & 65 & 66 & 56 \\
\hline & $\%$ Deviation in value w.r.t. national avg. & $63 \%$ & $86 \%$ & $116 \%$ & $118 \%$ & \\
\hline \multirow{3}{*}{ Beverages } & $\%$ Population reported consumption & 96 & 99 & 98 & 99 & 99 \\
\hline & Value of per capita consumption (₹) & 31 & 41 & 47 & 47 & 43 \\
\hline & $\%$ Deviation in value w.r.t. national avg. & $72 \%$ & $95 \%$ & $110 \%$ & $110 \%$ & \\
\hline \multirow{3}{*}{ Processed food } & $\%$ Population reported consumption & 98 & 97 & 95 & 97 & 97 \\
\hline & Value of per capita consumption (₹) & 117 & 103 & 145 & 139 & 127 \\
\hline & \% Deviation in value w.r.t. national avg. & $92 \%$ & $81 \%$ & $114 \%$ & $109 \%$ & \\
\hline
\end{tabular}

\section{Share of food items by MPCE classes}

Having looked at the pattern in expenditure on different food items and their inter-regional variations singularly, it would also be equally interesting to understand the regional pattern in the distribution of food expenditure across different food items. Among the regions, the Eastern region reported relatively higher share towards cereals both in rural and urban sector. Similarly, the expenditure on oil was higher in the Western region. Higher share of milk \&milk products was noticed in the Northern region, whereas egg, fish \&meat occupied relatively larger pie in the Eastern and Southern regions. Vegetables had marginally higher share in the Eastern region. Processed food, in the Southern region especially in rural sector, had relative higher share in food expenditure.

If we look at the region-wise expenditure on different food items across $\mathrm{MPCE}_{20}$ classes, the variations in share of expenditure on cereal, pulses, oil, vegetable, fruits and beverages in both rural and sector was almost uniform, barring few exceptions like in the Eastern region, the relative share of expenditure on cereals in urban sector registered steep decline with the improvement in $\mathrm{MPCE}_{20}$ classes. It is mainly due to higher share of cereal expenditure in lower rung of $\mathrm{MPCE}_{20}$ in the Eastern region, which tapered off significantly among the top $20 \%$ population. With the advancement in $\mathrm{MPCE}_{20}$ classes, the rise in relative share of expenditure on egg, fish \& meat was higher in the Eastern region. The share of expenditure on processed food increased sharply with the rise in total expenditure across all the regions in urban sector. The shift towards expenditure on processed food in urban sector was the highest among all food items, followed by milk \& milk products. In rural as well as urban sector both, with the progression of $\mathrm{MPCE}_{20}$ classes, the share of expenditure on milk \& milk products increased considerably in the Northern region, followed by the Western region.

Table 5(a): Region-wise share of various food items in total food expenditure Rural

\begin{tabular}{|c|c|c|c|c|c|c|c|c|c|c|c|}
\hline Region & $\mathrm{MPCE}_{20}$ & Food & $\begin{array}{c}\text { Cereal \& } \\
\text { cereal sub. }\end{array}$ & Pulses & Oil & $\begin{array}{c}\text { Milk \& milk } \\
\text { products }\end{array}$ & $\begin{array}{c}\text { Egg, fish \& } \\
\text { meat }\end{array}$ & $\begin{array}{c}\text { Vegetabl } \\
\text { es }\end{array}$ & $\begin{array}{c}\text { Fruits (Fresh \& } \\
\text { dry) }\end{array}$ & $\begin{array}{c}\text { Beverag } \\
\text { es }\end{array}$ & $\begin{array}{c}\text { Processed } \\
\text { food }\end{array}$ \\
\hline \multirow{6}{*}{ East } & 1 & 100 & 39 & 6 & 8 & 7 & 8 & 14 & 1 & \begin{tabular}{|l|} 
\\
\end{tabular} & 8 \\
\hline & 2 & 100 & 35 & 6 & 8 & 9 & 10 & 13 & 2 & 2 & 8 \\
\hline & 3 & 100 & 33 & 6 & 8 & 11 & 11 & 12 & 2 & 2 & 8 \\
\hline & 4 & 100 & 31 & 6 & 8 & 12 & 13 & 12 & 3 & 3 & 7 \\
\hline & 5 & 100 & 26 & 5 & 7 & 12 & 15 & 11 & 5 & 3 & 10 \\
\hline & All & 100 & 33 & 6 & 8 & 10 & 11 & 12 & 2 & 2 & 8 \\
\hline \multirow{6}{*}{ North } & 1 & 100 & 31 & 9 & 10 & 13 & 3 & 12 & 2 & 2 & 8 \\
\hline & 2 & 100 & 26 & 8 & 9 & 21 & 3 & 11 & 2 & 3 & 8 \\
\hline & 3 & 100 & 23 & 7 & 8 & 27 & 3 & 10 & 3 & 3 & 7 \\
\hline & 4 & 100 & 20 & 6 & 7 & 32 & 3 & 9 & 3 & 4 & 6 \\
\hline & 5 & 100 & 15 & 5 & 6 & 39 & 3 & 8 & 5 & 4 & 7 \\
\hline & All & 100 & 21 & 6 & 7 & 30 & 3 & 9 & 3 & 3 & 7 \\
\hline \multirow{6}{*}{ South } & 1 & 100 & 28 & 8 & 8 & 10 & 8 & 9 & 4 & 4 & 9 \\
\hline & 2 & 100 & 25 & 8 & 8 & 11 & 8 & 10 & 5 & 4 & 10 \\
\hline & 3 & 100 & 24 & 7 & 7 & 13 & 10 & 9 & 5 & 4 & 11 \\
\hline & 4 & 100 & 23 & 8 & 7 & 14 & 11 & 9 & 6 & 4 & 10 \\
\hline & 5 & 100 & 20 & 6 & 6 & 13 & 14 & 8 & 7 & 5 & 13 \\
\hline & All & 100 & 22 & 7 & 6 & 13 & 12 & 9 & 6 & 5 & 11 \\
\hline West & 1 & 100 & 31 & 10 & 11 & 7 & 3 & 12 & 2 & 3 & 10 \\
\hline
\end{tabular}




\begin{tabular}{|c|c|c|c|c|c|c|c|c|c|c|c|}
\hline & 2 & 100 & 26 & 9 & 10 & 14 & 4 & 11 & 3 & 3 & 9 \\
\hline & 3 & 100 & 25 & 9 & 10 & 18 & 4 & 9 & 4 & 3 & 8 \\
\hline & 4 & 100 & 23 & 8 & 10 & 20 & 4 & 9 & 5 & 4 & 8 \\
\hline & 5 & 100 & 19 & 7 & 9 & 23 & 5 & 8 & 6 & 4 & 10 \\
\hline & All & 100 & 23 & 8 & 10 & 18 & 4 & 9 & 5 & 4 & 9 \\
\hline \multirow{6}{*}{ All India } & 1 & 100 & 34 & 8 & 9 & 9 & 6 & 12 & 2 & 2 & 9 \\
\hline & 2 & 100 & 29 & 7 & 9 & 14 & 7 & 11 & 3 & 3 & 8 \\
\hline & 3 & 100 & 27 & 7 & 8 & 17 & 7 & 10 & 3 & 3 & 8 \\
\hline & 4 & 100 & 24 & 7 & 8 & 20 & 7 & 10 & 4 & 4 & 8 \\
\hline & 5 & 100 & 19 & 6 & 7 & 24 & 8 & 8 & 6 & 4 & 10 \\
\hline & All & 100 & 25 & 7 & 8 & 19 & 7 & 10 & 4 & 3 & 9 \\
\hline
\end{tabular}

Table 5(b): Region-wise share of various food items in total food expenditure Urban

\begin{tabular}{|c|c|c|c|c|c|c|c|c|c|c|c|}
\hline Region & $\mathrm{MPCE}_{20}$ & Food & $\begin{array}{c}\text { Cereal \& } \\
\text { cereal sub. }\end{array}$ & Pulses & Oil & \begin{tabular}{|c|}
$\begin{array}{c}\text { Milk \& milk } \\
\text { products }\end{array}$ \\
\end{tabular} & $\begin{array}{c}\text { Egg, fish } \\
\text { \& meat }\end{array}$ & Vegetables & \begin{tabular}{|c|} 
Fruits (Fresh \\
\& dry) \\
\end{tabular} & Beverages & $\begin{array}{c}\text { Processed } \\
\text { food }\end{array}$ \\
\hline \multirow{6}{*}{ East } & 1 & 100 & 35 & 6 & 8 & 8 & 11 & 13 & 2 & 2 & 8 \\
\hline & 2 & 100 & 30 & 5 & 8 & 10 & 14 & 12 & 3 & 3 & 8 \\
\hline & 3 & 100 & 26 & 5 & 8 & 12 & 14 & 11 & 4 & 3 & 10 \\
\hline & 4 & 100 & 22 & 4 & 7 & 11 & 16 & 10 & 5 & 4 & 14 \\
\hline & 5 & 100 & 15 & 3 & 5 & 12 & 17 & 9 & 6 & 4 & 23 \\
\hline & All & 100 & 24 & 5 & 7 & 11 & 15 & 11 & 4 & 4 & 14 \\
\hline \multirow{6}{*}{ North } & 1 & 100 & 26 & 8 & 9 & 20 & 5 & 11 & 2 & 3 & 6 \\
\hline & 2 & 100 & 21 & 7 & 8 & 27 & 5 & 10 & 3 & 4 & 7 \\
\hline & 3 & 100 & 18 & 6 & 7 & 31 & 3 & 9 & 4 & 4 & 7 \\
\hline & 4 & 100 & 15 & 5 & 6 & 35 & 2 & 9 & 5 & 5 & 9 \\
\hline & 5 & 100 & 12 & 4 & 5 & 32 & 2 & 7 & 8 & 5 & 19 \\
\hline & All & 100 & 17 & 6 & 7 & 30 & 3 & 9 & 5 & 5 & 11 \\
\hline \multirow{6}{*}{ South } & 1 & 100 & 25 & 7 & 7 & 13 & 9 & 9 & 5 & 5 & 10 \\
\hline & 2 & 100 & 23 & 7 & 7 & 15 & 10 & 9 & 6 & 5 & 10 \\
\hline & 3 & 100 & 22 & 7 & 6 & 16 & 11 & 8 & 6 & 5 & 10 \\
\hline & 4 & 100 & 21 & 7 & 6 & 16 & 10 & 8 & 7 & 5 & 14 \\
\hline & 5 & 100 & 16 & 6 & 5 & 16 & 9 & 6 & 8 & 6 & 22 \\
\hline & All & 100 & 20 & 6 & 6 & 15 & 10 & 8 & 7 & 5 & 15 \\
\hline \multirow{6}{*}{ West } & 1 & 100 & 26 & 9 & 11 & 14 & 4 & 10 & 4 & 4 & 7 \\
\hline & 2 & 100 & 23 & 8 & 10 & 19 & 5 & 10 & 5 & 4 & 7 \\
\hline & 3 & 100 & 20 & 7 & 9 & 20 & 5 & 10 & 6 & 5 & 9 \\
\hline & 4 & 100 & 18 & 6 & 8 & 22 & 5 & 10 & 7 & 5 & 12 \\
\hline & 5 & 100 & 13 & 5 & 6 & 21 & 5 & 7 & 9 & 5 & 24 \\
\hline & All & 100 & 18 & 6 & 8 & 20 & 5 & 9 & 7 & 5 & 14 \\
\hline \multirow{6}{*}{ All India } & 1 & 100 & 28 & 8 & 9 & 15 & 7 & 11 & 3 & 3 & 7 \\
\hline & 2 & 100 & 23 & 7 & 8 & 18 & 8 & 10 & 4 & 4 & 8 \\
\hline & 3 & 100 & 21 & 7 & 8 & 21 & 8 & 10 & 5 & 4 & 9 \\
\hline & 4 & 100 & 19 & 6 & 7 & 22 & 7 & 9 & 6 & 5 & 12 \\
\hline & 5 & 100 & 14 & 5 & 5 & 22 & 7 & 7 & 8 & 5 & 22 \\
\hline & All & 100 & 19 & 6 & 7 & 20 & 7 & 9 & 6 & 5 & 14 \\
\hline
\end{tabular}

Socio-economic and regional factors influencing consumption expenditure of different food items

We have seen that there are considerable variations in consumption as we move through the various MPCE classes or through the regions. Past research also indicate that there is significant influence of social and demographic factors on food consumption pattern (Harriss-White and Hoffenberg, 1994) [9]. To estimate the effect of various factors on consumer expenditure of various food items, multiple regressions analysis was carried out. We have taken into consideration factors like household size, regions, occupation types and social class. The analysis reveals that both in rural and urban areas, the variations in dependent variable i.e., consumer expenditure is relatively much influenced by these variablesin case of Cereals \& Cereal substitutes, Pulses, Milk\& Milk Products, Oil and Vegetables. Food items such as egg, fish \& meat, fruits, beverages and processed foods don't have high $\mathrm{R}^{2}$ value.

Table 6(a): Multiple Linear Regression Analysis: Effects of Regional and Socio-Economic variables on Consumer expenditure of food items (Rural India)

\begin{tabular}{|c|c|c|c|c|c|c|c|c|c|c|}
\hline \multirow[b]{2}{*}{ Explanatory variable } & \multicolumn{10}{|c|}{ Unstandardized coefficients } \\
\hline & \begin{tabular}{|c|}
$\begin{array}{c}\text { Cereals \& cereals } \\
\text { substitutes }\end{array}$ \\
\end{tabular} & Pulses & $\begin{array}{c}\text { Milk \& milk } \\
\text { products }\end{array}$ & Oil & \begin{tabular}{|c|} 
Egg, fish \& \\
meat
\end{tabular} & Vegetables & Fruits & Beverage & $\begin{array}{l}\text { Processed } \\
\text { food }\end{array}$ & $\begin{array}{l}\text { Total } \\
\text { food }\end{array}$ \\
\hline Constant & 26.40 & 75.95 & 694.87 & 109.92 & 25.43 & 152.89 & 81.81 & 83.14 & 107.69 & 1517.93 \\
\hline Household size & $142.22 *$ & $30.22 *$ & $84.61 *$ & $32.36^{*}$ & $30.11^{*}$ & $36.46^{*}$ & $15.66 *$ & $10.84 *$ & $33.93 *$ & $452.10^{*}$ \\
\hline
\end{tabular}




\begin{tabular}{|c|c|c|c|c|c|c|c|c|c|c|c|}
\hline \multirow{3}{*}{$\begin{array}{l}\widetilde{0} \\
.00 \\
\stackrel{0}{0} \\
\simeq\end{array}$} & East & $250.90^{*}$ & $-47.61 *$ & $-670.12 *$ & $-24.63 *$ & $211.85^{*}$ & $31.65^{*}$ & $-34.09 *$ & $-39.17 *$ & $0.55^{*}$ & $-425.36^{*}$ \\
\hline & West & $61.42 *$ & $32.16^{*}$ & $-424.24 *$ & $53.27 *$ & $39.95^{*}$ & $-21.07 *$ & $42.30 *$ & $0.17 *$ & $43.27 *$ & $-186.60 *$ \\
\hline & South & $140.45^{*}$ & $27.52 *$ & $-489.32 *$ & $-19.92 *$ & $287.59^{*}$ & $-18.45^{*}$ & $92.19 *$ & $33.38^{*}$ & $135.39 *$ & $169.98 *$ \\
\hline \multirow{5}{*}{ 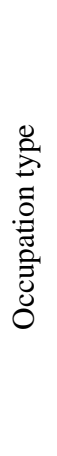 } & Self employed in agri. & 1.370 & $6.07 *$ & $147.44^{*}$ & $-5.94 *$ & $-59.61 *$ & $-9.68 *$ & $-9.89 *$ & $-23.11 *$ & $-53.28 *$ & $-3.41 *$ \\
\hline & $\begin{array}{c}\text { Regular wage/ salary } \\
\text { earnings }\end{array}$ & $41.27 *$ & $13.49 *$ & $144.99 *$ & $11.25^{*}$ & $20.55^{*}$ & $20.95^{*}$ & $36.46 *$ & $39.68^{*}$ & $126.41 *$ & $469.63^{*}$ \\
\hline & Casual labour in agri. & $-78.92 *$ & $-22.40 *$ & $-92.66 *$ & $-30.42 *$ & $-92.66^{*}$ & $-28.74 *$ & $-51.47 *$ & $-36.15^{*}$ & $-70.88^{*}$ & $-526.09^{*}$ \\
\hline & $\begin{array}{l}\text { Casual labour in non- } \\
\text { agri. }\end{array}$ & $-70.30 *$ & $-23.90 *$ & $-128.28 *$ & $-27.52 *$ & $-33.33^{*}$ & $-32.34 *$ & $-33.49 *$ & $-15.01 *$ & $-5.98 *$ & $-391.39 *$ \\
\hline & Other occupation & $-68.11 *$ & $-28.15 *$ & -16.91 & $-36.34 *$ & $-72.33 *$ & $-42.57^{*}$ & $-17.66 *$ & $-36.51 *$ & $107.47 *$ & $-242.22 *$ \\
\hline \multirow{3}{*}{ 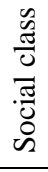 } & ST & $-123.21 *$ & $-35.94 *$ & $-360.63 *$ & $-58.75 *$ & $-19.71 *$ & $-45.39 *$ & $-84.14 *$ & $-31.77 *$ & $-48.05^{*}$ & $-870.90 *$ \\
\hline & $\mathrm{SC}$ & $-87.69 *$ & $-25.07 *$ & $-292.67 *$ & $-28.77 *$ & $-50.27 *$ & $-30.70 *$ & $-59.60 *$ & $-20.28^{*}$ & $-44.35^{*}$ & $-676.16^{*}$ \\
\hline & $\mathrm{OBC}$ & $-71.27 *$ & $-12.27 *$ & $-177.31 *$ & $-22.36 *$ & $-67.24 *$ & $-23.86^{*}$ & $-47.01 *$ & $-18.72 *$ & $-58.36^{*}$ & $-525.25^{*}$ \\
\hline & Adjusted $\mathrm{R}^{2}$ & 0.54 & \begin{tabular}{|l|}
0.32 \\
\end{tabular} & 0.28 & \begin{tabular}{|l|}
0.34 \\
\end{tabular} & 0.15 & 0.28 & 0.16 & 0.15 & 0.04 & 0.43 \\
\hline
\end{tabular}

* all variables are significant at 5 percent level

Source: Author's computation from unit level 68th consumer expenditure, type -I

Expectedly, as the family size increases the probability of expenditure on all food items mentioned in the above table increases in rural areas while in urban areas except processed food all food items are positively impacted in bigger families. Also, more of cereals \& cereal substitutes are consumed in the Eastern, Southern \& Western Regions as compared to Northern region which is exactly opposite to milk \& milk products. Northern region spends the most in case of milk and milk products when compared to all other regions both in urban and rural India, where eastern region shows the least relative consumption, followed by South. In case of pulses both in rural and urban areas of the country, the eastern region spends the least, while the western and southern region spend more as compared to northern region.

Households with their chief occupation as "self-employed in agriculture" and "regular wage and salaried class" consume more of cereals, pulses and milk \& milk products while "casual labour in agriculture and non-agriculture" and "other occupation" consume less of these items when compared to "self-employed in non-agriculture" households in rural areas. In urban areas, the salaried households spend more on all food items in comparison to all other occupation type.

Table 6(b): Multiple Linear Regression Analysis:Effects of Regional and Socio-Economic variables on Consumer expenditure of food items (Urban India)

\begin{tabular}{|c|c|c|c|c|c|c|c|c|c|c|c|}
\hline \multirow{2}{*}{\multicolumn{2}{|c|}{ Explanatory variable }} & \multicolumn{10}{|c|}{ Unstandardized coefficients } \\
\hline & & $\begin{array}{c}\text { Cereals \& } \\
\text { cereals sub. }\end{array}$ & Pulses & $\begin{array}{c}\text { Milk \& milk } \\
\text { products }\end{array}$ & Oil & $\begin{array}{c}\text { Egg, fish \& } \\
\text { meat }\end{array}$ & Vegetables & Fruits & Beverage & $\begin{array}{l}\text { Processed } \\
\text { food }\end{array}$ & $\begin{array}{l}\text { Total } \\
\text { food }\end{array}$ \\
\hline \multicolumn{2}{|c|}{ Constant } & 40.57 & 60.60 & 824.44 & 74.49 & -54.13 & 170.03 & 156.84 & 155.63 & 690.81 & 2237.43 \\
\hline \multicolumn{2}{|c|}{ Household size } & $161.28 *$ & $43.13 *$ & $132.44 *$ & $49.31 *$ & $52.72 *$ & $52.87 *$ & $31.53 *$ & $17.28 *$ & $-14.96^{*}$ & $575.55 *$ \\
\hline \multirow{3}{*}{ 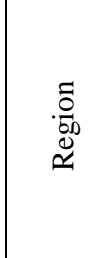 } & East & $237.36^{*}$ & $-42.91 *$ & $-790.56^{*}$ & -0.02 & $399.74 *$ & $34.58 *$ & $-63.42 *$ & $-51.53 *$ & -13.66 & $-371.14^{*}$ \\
\hline & West & $84.86^{*}$ & $34.80 *$ & $-364.59 *$ & $75.48 *$ & $77.47^{*}$ & $13.11^{*}$ & $63.20^{*}$ & $14.24 *$ & $93.34 *$ & $82.07 *$ \\
\hline & South & $170.12 *$ & $41.97 *$ & $-479.02 *$ & $-15.90 *$ & $268.90 *$ & $-40.68 *$ & $76.41^{*}$ & $16.65^{*}$ & $71.91 *$ & $94.68^{*}$ \\
\hline \multirow{3}{*}{ 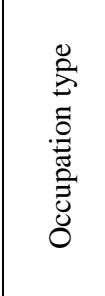 } & $\begin{array}{c}\text { Self } \\
\text { employed }\end{array}$ & $-53.69 *$ & $-10.96 *$ & $-13.86^{*}$ & -2.30 & $-35.89 *$ & $-14.99 *$ & $-25.90 *$ & $-29.14 *$ & $-132.97 *$ & $-325.34 *$ \\
\hline & $\begin{array}{l}\text { Casual } \\
\text { labour }\end{array}$ & $-163.54 *$ & $-48.55 *$ & $-339.59 *$ & $-56.26 *$ & $-57.72 *$ & $-75.64 *$ & $-115.31 *$ & $-66.89 *$ & $-209.51 *$ & $-1168.89 *$ \\
\hline & $\begin{array}{c}\text { Other } \\
\text { occupation }\end{array}$ & $-98.58 *$ & $-36.33 *$ & $-104.72 *$ & $-41.72 *$ & $-55.84 *$ & $-71.05 *$ & $-29.68 *$ & $-60.29 *$ & $155.99 *$ & $-381.22 *$ \\
\hline 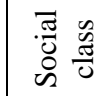 & ST & $-64.20 *$ & $-35.15 *$ & $-286.50 *$ & $-49.02 *$ & $-37.90 *$ & $-30.74 *$ & $-108.95 *$ & $-42.25 *$ & $-232.87 *$ & $-926.81 *$ \\
\hline
\end{tabular}




\begin{tabular}{|c|c|c|c|c|c|c|c|c|c|c|c|}
\hline & SC & $-81.30^{*}$ & $-29.28^{*}$ & $-359.16^{*}$ & $-36.52^{*}$ & $-56.68^{*}$ & $-53.69^{*}$ & $-129.82^{*}$ & $-54.61^{*}$ & $-222.91^{*}$ & $-1055.93^{*}$ \\
\cline { 2 - 19 } & OBC & $-66.21^{*}$ & $-28.05^{*}$ & $-272.80^{*}$ & $-34.15^{*}$ & $-47.74^{*}$ & $-48.37^{*}$ & $-100.80^{*}$ & $-45.92^{*}$ & $-168.64^{*}$ & $-838.27^{*}$ \\
\hline Adjusted R ${ }^{2}$ & 0.58 & 0.38 & 0.33 & 0.45 & 0.16 & 0.34 & 0.11 & 0.10 & 0.01 & 0.30 \\
\hline
\end{tabular}

* all variables are significant at 5 percent level

Source: Author's computation from unit level 68th consumer expenditure, type -I

The effect of social class is uniform across all food items. When compared to the "general" category the SCs, STs, and OBCs have lesser likelihood to spend on all food items in both urban and rural areas.

\section{Consumption inequalities}

To substantiate the regional variation and changing pattern with the change in $\mathrm{MPCE}_{20}$ classes, the consumption inequalities for major food articles have been attempted. The inequalities have been measured with the help of Lorenz Curve. A Lorenz curve is a cumulative frequency curve and essentially used to measure how equally or unequally population and consumption expenditure are distributed in the society. The Lorenz curve and Lorenz ratio are indicators of inequality. The Lorenz ratio provides a summary measure of relative inequality based on the Lorenz curve. Concentration curve and concentration ratio are generalizations of Lorenz curve and Lorenz ratio, respectively. The value of the concentration ratio ranges from 0 to 1 . Lower the ratio, lesser the inequality in the society, the distribution of the assets/ expenditure is more even and vice-a-versa.

The concentration ratios for different food articles have been estimated across the regions. The Lorenz ratio for total consumption expenditure was 0.308 and 0.386 in rural and urban India respectively. In comparison to national inequality in total consumption expenditure, it was higher in the
Southern parts of the country in the rural sector and the same was higher in the Northern region in urban sector. Notably, the inequality was much lower in Eastern region in rural sector. Similarly, the Western region exhibited lower disparity in both rural and urban sector as compared to national estimates of inequality.

Across different food items, the consumption expenditure on cereals expectedly showed the lowest inequality both in rural and urban sector. Also, the inequalities in case of pulses, oil and vegetables were lower in rural and urban India. The inequality coefficients were relatively higher in milk $\&$ milk products, egg, fish \& meat, fruits and beverages in rural sector, whereas it was higher in case of fruits and processed food in urban sector. In rural sector, the inequality was the highest in the Northern region in milk \& milk products, while in case of egg, fish \& meat, it was the highest in the Southern region. The expenditure on milk \& milk products was more equitably distributed in urban sector as compared to rural counterpart and so was the case of egg, fish \& meat. However, among all four regions, the Eastern region showed comparatively greater disparity in consumption expenditure of these two items in urban sector. Higher disparity may be noticed in expenditure towards processed food in urban segment of the country and it has been more or less uniform across all the regions.

Table 6(a): Concentration ratio of various food items, Rural

\begin{tabular}{|c|c|c|c|c|c|}
\hline Items & East & North & South & West & All India \\
\hline Cereal & 0.107 & 0.076 & 0.126 & 0.118 & 0.090 \\
\hline Pulses & 0.155 & 0.123 & 0.139 & 0.144 & 0.157 \\
\hline Oil & 0.152 & 0.115 & 0.117 & 0.176 & 0.141 \\
\hline Milk and milk products & 0.319 & 0.399 & 0.231 & 0.368 & 0.381 \\
\hline Egg, fish \& meat & 0.310 & 0.251 & 0.321 & 0.292 & 0.309 \\
\hline Vegetables & 0.138 & 0.145 & 0.142 & 0.137 & 0.130 \\
\hline Fruits & 0.467 & 0.436 & 0.310 & 0.399 & 0.436 \\
\hline Beverages & 0.267 & 0.308 & 0.241 & 0.309 & 0.316 \\
\hline Processed food & 0.223 & 0.233 & 0.303 & 0.250 & 0.270 \\
\hline All food items & 0.174 & 0.221 & 0.187 & 0.204 & 0.204 \\
\hline MPCE (Total exp.) & 0.247 & 0.304 & 0.338 & 0.305 & 0.308 \\
\hline
\end{tabular}

Table 6(b): Concentration ratio of various food items, Urban

\begin{tabular}{|c|c|c|c|c|c|}
\hline Items & East & North & South & West & All India \\
\hline Cereal & 0.081 & 0.093 & 0.137 & 0.108 & 0.106 \\
\hline Pulses & 0.146 & 0.136 & 0.158 & 0.117 & 0.148 \\
\hline Oil & 0.170 & 0.132 & 0.132 & 0.136 & 0.141 \\
\hline Milk and milk products & 0.337 & 0.330 & 0.248 & 0.300 & 0.307 \\
\hline Egg, fish \& meat & 0.350 & 0.135 & 0.220 & 0.275 & 0.262 \\
\hline Vegetables & 0.163 & 0.178 & 0.150 & 0.183 & 0.164 \\
\hline Fruits & 0.474 & 0.497 & 0.323 & 0.398 & 0.420 \\
\hline Beverages & 0.375 & 0.354 & 0.281 & 0.298 & 0.325 \\
\hline Processed food & 0.502 & 0.526 & 0.437 & 0.544 & 0.505 \\
\hline All food items & 0.243 & 0.255 & 0.213 & 0.242 & 0.239 \\
\hline MPCE (Total exp.) & 0.388 & 0.405 & 0.377 & 0.367 & 0.386 \\
\hline
\end{tabular}

\section{Concluding Observations}

Looking at the vast geographical spread, diverse topography, cultural variety and the food habits, the regions of India are stylized and summarized below based on the analyses of consumer expenditure on different food articles.
Eastern region:(i) Higher proportion of rural population,(ii) higher population belonging to $\mathrm{MPCE}_{20}$ class 1 \& 2, (iii) lowest per capita expenditure, (iv) higher share of food expenditure in MPCE, (v) higher allocation of food expenditure on cereals \& cereal substitutes especially in 
bottom classes of $\mathrm{MPCE}_{20}$, (vi) higher incidence coupled with higher consumer expenditure on egg, fish \& meat as against low incidence and expenditure towards milk \& milk products, (vii) lowest expenditure on animal protein foods, (viii) lowest disparity in MPCE in rural sector, (ix) high inequality in expenditure on milk \& milk products and egg, fish \& meat.

Northern region: (i) Highest share of the region in country's rural population coupled with lower proportion of urban population in the region, (ii) relatively higher proportion of population belonged to upper classes in $\mathrm{MPCE}_{20}$ in rural sector, where as in urban sector higher proportion belonged to bottom $20 \%$, (iii) higher MPCE in both the sectors, (iv) milk $\&$ milk products were the major source of animal protein in the region as the region had the highest expenditure on milk \& milk products and the lowest towards egg, fish \& meat,(v) milk \& milk products accounted for the highest share in total food expenditure in both the sectors, (vi) highest disparity in MPCE in urban sector, (vii) higher contribution of expenditure pattern on milk \& milk productsin inequality.

Southern region:(i) Lowest share of the region in country's rural population, (ii) higher proportion of urban population in the region, (iii) lower population belonging to $\mathrm{MPCE}_{20}$ class 1 $\& 2$ and consequently, higher proportion in class $4 \& 5$, (iv) highest MPCE in both rural and urban sector, (v) lowest share of food expenditure in MPCE, (vi) highest fall in share of food expenditure with the progression in $\mathrm{MPCE}_{20}$ classes, (vii) higher expenditure on egg, fish \& meat, fruits, beverages and processed food, (viii) the intake of animal protein was equally distributed between milk \& milk products and egg, fish \& meat, (ix) highest disparity in MPCE in rural sector, (x) lowest disparity in expenditure on milk \& milk products across all four regions.

Western region:(i) Highest share of the region in country's urban population resulting in the highest proportion of urban population across all the regions, (ii) lower population belonging to $\mathrm{MPCE}_{20}$ class $1 \& 2$ in urban sector, (iii) MPCE more or less in tandem with the national average so was in case of majority of the food articles, (iv) highest expenditure on oil across the regions, (v) relatively higher incidence of expenditure on milk \& milk products and egg, fish \& meat in urban sector in comparison to rural sector, (vi) moderate to low consumer expenditure on animal protein foods (i.e., milk \& milk products \& egg, fish \& meat), (vii) the share of expenditure on processed food in urban sector increased sharply with the advancement in $\mathrm{MPCE}_{20}$, (vii) disparity in the MPCE and food expenditure in the region almost go along with the national pattern.

Thus, based on our findings each region has distinct features which are quite dissimilar from each other. Socio-economic factors such as occupation and social category also impact the consumption pattern both in urban and rural areas. Where there is lesser prosperity in terms of disposable income, major portion of total consumer expenditure is apportioned towards food basket in general and within the food spectrum, more towards staple food like cereals for e.g., eastern region. As we move towards richer class, the share of food expenditure decreases and so is the share of expenditure on cereals. This also confirms the Engel's law of demand, the rise in income and improvement in life style would tend to change the consumption pattern. With improvement in incomes, cereal consumption will be substituted by protein-rich and highvalued food items (Shah and Datta 2016) ${ }^{[15]}$.

\section{References}

1. Ali J. Structural Changes in Food Consumption and Nutritional Intake from Livestock Products in India, South Asia Research. 2007; 27(2):137-151.

2. Atibudhi HN. A Comparative Analysis of Food Consumption and Monthly per Capita Expenditure of Orissa vis-a-vis All India Level. Indian Journal of Agricultural Economics, 2006, 61(3).

3. CES. Unit Level Data of Consumer Expenditure Survey: URP. National Sample Survey Office, Ministry of Statistics and Programme Implementation, Government of India, 2014.

4. Deaton, Angus. The Analysis of Household Surveys: A Micro econometric Approach to Development Policy, Washington, DC, The World Bank, 1997, 3p.

5. Giri AK. Cereal Consumption over Time in the Country and across the States. Indian Journal of Agricultural Economics, 2006, 61(3).

6. Golait R, Pradhan NC. Changing Food Consumption Pattern in Rural India: Implication on Food and Nutrition Security. Indian Journal of Agricultural Economics, 2006, 61(3)

7. Gupta A, Mishra DK. Poverty and calorie deprivation across socio-economic groups in rural India: a disaggregated analysis. Journal of Regional Development and Planning. 2013; 2(1):15-33.

8. Gupta A, Mishra DK. Food consumption pattern in Rural India: A regional perspective. Journal of Economic \& Social Development. 2014; X(1):1-16.

9. Harriss-White B, Raymond Hoffenberg. eds. Food: Multidisciplinary Perspectives, Blackwell, Oxford, 1994.

10. Murthy MN. Sampling theory and Methods, Calcutta: Statistical Publishing Society, 1967, 3p.

11. Nasurudeen P, Kuruvila A, Sendhil R, Chandresekar V. The Dynamics and Inequality of Nutrient Consumption in India. Indian Journal of Agriculture Economics. 2006; 61(3):362-373.

12. NCAER [National Council of Applied Economic Research]. An Analysis of Changing Food Consumption Pattern in India, Agriculture Outlook and Situation Analysis Report, 2014.

13. Radhakrishna R. Food Consumption and Nutritional Status in India: Emerging Trends and Perspectives, Working Paper, November, Indira Gandhi Institute of Development Research, Mumbai, 2006.

14. Radhakrishna R, Reddy V. Food Security and Nutrition: Vision 2020, [Online] Availableat: planningcommi ssion.nic.in/reports/.../bkpap2020/16_Bg2020.pdf.

15. Shah Jignesh, Datta TN. Diversity in Food Basket Grows with Rising Income, Dairy India Yearbook, Edition Seven, 2016, 119-124p.

16. Shariff A, Mallick AC. Dynamics of Food Intake and Nutrition by Expenditure Class in India, Economicand Political Weekly. 1999; 34(27):1790-1800.

17. Singh RK, Vishwakarma A, Singh PK. Food Security and Policy Perspective in India, Indian Journal of Agricultural Economics, 2006, 61(3).

18. Viswanathan B. Structural Breaks in Consumption Patterns: India 1952-1991, Applied Economics. 2001; 33(9):1187-1200. 